\title{
Correction to: Mental Health and Religiosity in the Sardinian Blue Zone: Life Satisfaction and Optimism for Aging Well
}

\author{
Maria Chiara Fastame ${ }^{1}$ (D) Marilena Ruiu ${ }^{1} \cdot$ Ilaria Mulas $^{1}$
}

Published online: 19 May 2021

(c) The Author(s) 2021

\section{Correction to: Journal of Religion and Health https://doi.org/10.1007/s10943-021-01261-2}

In the original publication of the article, the author noticed the errors in the reference citation.

The corrected text citations are given below:

In section, "Well-Being in the Sardinian Blue Zone", last paragraph, the second sentence should read, "Extending this, the first longitudinal study conducted in the Sardinian Blue Zone recently documented that compared to national parameters, the older inhabitants of the longevity area displayed preserved motor efficiency, higher perceived psychological well-being, and fewer depressive symptoms even 2 years after the first assessment (Fastame, Mulas \& Pau, 2020)."

In Materials section, fourth paragraph, the first sentence should read," The SODdisfazione dell'Anziano (SODA) Questionnaire (Fastame, Penna \& Hitchcott, 2020) is a self-reported tool including 14 items designed to assess life satisfaction during the past week."

In Discussion and Conclusions, second paragraph, the last sentence should read, "Moreover, although the respondents of the rural and urban areas reported very high life satisfaction indexes (Fastame, Penna \& Hitchcott, 2020), it must be noticed that those of the Sardinian Blue Zone reported greater hedonic well-being".

The original article has been corrected.

Open Access This article is licensed under a Creative Commons Attribution 4.0 International License, which permits use, sharing, adaptation, distribution and reproduction in any medium or format, as long as

The original article can be found online at https://doi.org/10.1007/s10943-021-01261-2.

Maria Chiara Fastame

chiara.fastame@unica.it

1 Department of Pedagogy, Psychology, Philosophy, University of Cagliari, Via Is Mirrionis 1, 09123 Cagliari, Italy 
you give appropriate credit to the original author(s) and the source, provide a link to the Creative Commons licence, and indicate if changes were made. The images or other third party material in this article are included in the article's Creative Commons licence, unless indicated otherwise in a credit line to the material. If material is not included in the article's Creative Commons licence and your intended use is not permitted by statutory regulation or exceeds the permitted use, you will need to obtain permission directly from the copyright holder. To view a copy of this licence, visit http://creativecommons.org/licen ses/by/4.0/.

\section{References}

Fastame, M. C., Mulas, I., \& Pau, M. (2020). Mental health and motor efficiency of older adults living in the Sardinia's Blue Zone: a follow-up study. International Psychogeriatrics, 1-12. https://doi.org/ 10.1017/S1041610220001659

Fastame, M. C., Penna, M. P., \& Hitchcott, P. K. (2020). SODA: A new questionnaire for the assessment of life satisfaction in late life span. Aging Clinical and Experimental Research, 32, 515-533. https:// doi.org/10.1007/s40520-019-01211-9

Publisher's Note Springer Nature remains neutral with regard to jurisdictional claims in published maps and institutional affiliations. 